\title{
Hereditary Coproporphyria
}

National Cancer Institute

\section{Source}

National Cancer Institute. Hereditary Coproporphyria. NCI Thesaurus. Code C84759.

An autosomal dominant inherited disorder of porphyrin metabolism caused by deficiency

of the enzyme coproporphyrinogen oxidase. It results in neurologic damage and can

include abdominal pain, constipation and psychiatric manifestations. 